\title{
PENGARUH KOMPETENSI PEDAGOGIK GURU TERHADAP MOTIVASI BELAJAR PESERTA DIDIK DI MADRASAH ALIYAH SERBA BAKTI TASIKMALAYA
}

\author{
Nurhayati ${ }^{1}$, Nurhamzah $\mathrm{CS}^{2}$, Wawan ${ }^{3}$ \\ Institut Agama Islam Latifah Mubarokiyah, Tasikmalaya, Indonesia \\ nurhayatinunuy181@gmail.com ${ }^{1}$, hamzahcs35@gmail.com²,wawan070869@gmail.com³
}

\begin{abstract}
Abstrack
This study aims to determine the positive effect between the teacher's pedagogical competencies on the learning motivation of students in the Madrasah Aliyah Serba Bakti of the Suryalaya Islamic Boarding School. The method used in this study is a descriptive method through a quantitative approach with a population of 357 people, and a sample of 36 people using data collection techniques namely questionnaires, observation, and documentation. To test variables $x$ and $y$ are done by determining the mean value which is interpreted using the interpretation scale classification, as well as for the relationship between variables $x$ and $y$ used Spearman Rank correlation analysis techniques, and hypothesis testing using t-test. Based on the results of data processing, it is found that the influence of teacher pedagogical competence on student motivation in Madrasah Aliyah Serba Bakti of the Suryalaya Islamic Boarding School has a significant positive effect with a sufficient category, proven $r s=0.522$ at intervals 0.41 to 0.60 and t_count (3.57) is greater instead of t_table (1,691). Teacher pedagogical competence determines student learning motivation by $27.25 \%$ while the remaining $72.75 \%$ is determined by other factors.
\end{abstract}

Keywords: Pedagogical Competence; Learning Motivation; Student

\begin{abstract}
Abstrak
Penelitian ini bertujuan untuk mengetahui pengaruh yang positif antara kompetensi pedagogik guru terhadap motivasi belajar peserta didik di Madrasah Aliyah Serba Bakti Pondok Pesantren Suryalaya. Metode yang digunakan dalam penelitian ini adalah metode deskriptif melalui pendekatan kuantitatif dengan populasi sebanyak 357 orang, dan sampel 36 orang dengan menggunakan teknik pengumpulan data yaitu angket, observasi, dan dokumentasi. Untuk menguji variabel $\mathrm{x}$ dan y dilakukan dengan ditentukannya nilai mean yang diinterpretasikan menggunakan klasifikasi skala penafsiran, serta untuk hubungan antara variabel $\mathrm{x}$ dan y digunakan teknik analisis korelasi Rank Spearman, dan uji hipotesis menggunakan uji t. Berdasarkan hasil pengolahan data diperoleh bahwa pengaruh kompetensi pedagogik guru terhadap motivasi belajar peserta didik di Madrasah Aliyah Serba Bakti Pondok Pesantren Suryalaya mempunyai pengaruh positif yang signifikan dengan kategori cukup, terbukti rs $=0,522$ berada pada interval $0,41-0,60$ serta $t_{\text {hitung }}(3,57)$ lebih besar daripada $t_{\text {tabel }}(1,691)$. Kompetensi pedagogik guru menentukan motivasi belajar peserta didik sebesar 27,25\% sedangkan sisanya 72,75\% ditentukan oleh faktor lain.
\end{abstract}

Kata Kunci: Kompetensi Pedagogik; Motivasi Belajar; Peserta Didik 


\section{A. PENDAhULUAN}

Pendidikan merupakan kebutuhan manusia yang sangat penting, karena pendidikan mempunyai tugas untuk menyiapkan sumber daya manusia bagi pembangunan bangsa dan Negara. Pendidikan adalah suatu proses mengembangkan semua aspek kepribadian manusia yang mencakup pengetahuan, nilai dan sikapnya, serta keterampilannya.

Salah satu komponen penting dalam pendidikan adalah guru. Guru dalam konteks pendidikan mempunyai peranan yang besar. Hal ini disebabkan gurulah yang berada di barisan terdepan dalam pelaksanaan pendidikan. Gurulah yang langsung berhadapan dengan peserta didik untuk mentransfer ilmu pengetahuan dan teknologi sekaligus mendidik dengan nilai-nilai positif melalui bimbingan dan keteladanan.

Agama Islam juga sangat menghargai orang-orang yang berilmu pengetahuan (guru/ulama), sehingga hanya mereka sajalah yang pantas mencapai taraf ketinggian dan keutuhan hidup. Sebagaimana firman Allah Swt dalam surat Al-Mujadalah ayat 11 yang berbunyi:

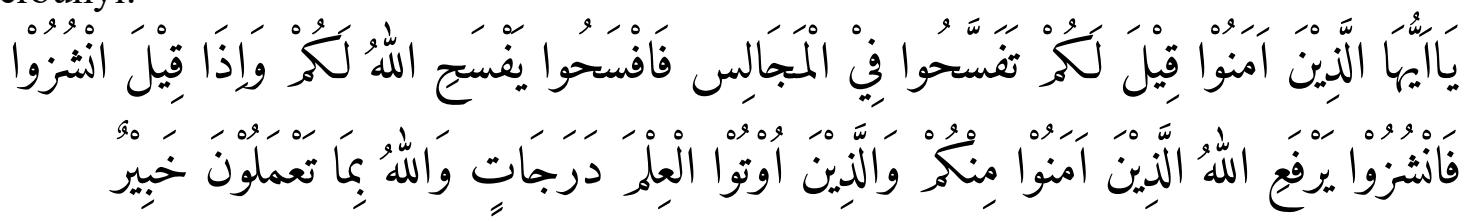

Artinya: "Hai orang-orang beriman apabila kamu dikatakan kepadamu: "Berlapang-lapanglah dalam majlis", Maka lapangkanlah niscaya Allah akan memberi kelapangan untukmu. Dan apabila dikatakan: "Berdirilah kamu", Maka berdirilah, niscaya Allah akan meninggikan orang-orang yang beriman di antaramu dan orangorang yang diberi ilmu pengetahuan beberapa derajat. Dan Allah Maha mengetahui apa yang kamu kerjakan.” (Tim Penerjemah Al-Qur'an Depag RI 2009: 543).

Seorang guru harus memiliki intelektual yang tinggi untuk dapat melaksanakan peranannya secara profesional yang dalam tugasnya guru tidak hanya mengajar dan melatih tetapi juga mendidik. Guru tidak hanya menyampaikan materi kepada peserta didik namun menjadikan peserta didik belajar yang ditandai dengan adanya suatu perubahan setelah terjadinya proses pembelajaran. Guru harus bisa menggali potensi yang ada dalam diri setiap peserta didik, agar potensi mereka dapat terberdayakan dengan baik.

Kompetensi pedagogik merupakan salah satu jenis kompetensi yang mutlak harus dikuasai guru. Kompetensi pedagogik ini merupakan kemampuan mengelola pembelajaran yang mencakup konsep kesiapan mengajar, yang ditunjukkan oleh penguasaan pengetahuan dan ketrampilan mengajar. Kompetensi pedagogik yang harus dimiliki oleh seorang guru antara lain pemahaman terhadap peserta didik, perancangan, pelaksanaan dan evaluasi pembelajaran. Selain itu kompetensi pedagogik juga mencerminkan kemampuan guru, kemampuan menjalajahi ilmu pengetahuan, dan menampilkan sikap positif terhadap keseluruhan tugasnya. Peran guru sebagai fitur sentral dalam proses pembelajaran tidak lepas dari kemampuan pedagogik yang melekat pada dirinya. 
Proses pembelajaran dapat terlaksana dengan baik jika didukung oleh kompetensi yang dimiliki oleh guru, apalagi jika proses pembelajaran tersebut diselenggarakan secara interaktif, inspiratif, menyenangkan, menantang, dan memotivasi peserta didik untuk berpartisipasi aktif dalam pembelajaran.

Kemampuan pedagogoik guru secara langsung mempunyai pengaruh yang sangat besar terhadap motivasi belajar peserta didik. Jika guru bisa menyampaikan pelajaran sesuai dengan harapan peserta didik maka akan membuat proses belajar mengajar tersebut berjalan dengan efektif dan efisien. (https://scholar.google.com, MN Jamal-repository.uin-alauddin.ac.id, 2017, tersedia).

Namun pada kenyataanya, meskipun guru sudah memiliki kompetensi pedagogik yang cukup baik dewasa ini masih ada peserta didik yang motivasi belajarnya rendah, misalnya terlambat masuk sekolah, melalaikan tugas, gaduh pada saat jam pelajaran, membantah jika diperingatkan, merokok, serta sering tidak fokus dan tidak memperhatikan pelajaran yang disampaikan oleh guru saat mengajar di depan kelas. (Ernata, 2017, Vol. 5, No.2).

Berdasarkan hasil pengamatan di Madrasah Aliyah Serba Bakti Suryalaya, bahwa guru sudah mengajar seoptimal mungkin dengan kompetensi-kompetensi yang mereka miliki. Khususnya kompetensi pedagogik-pun sudah dimiliki oleh guru Madrasah Aliyah Serba Bakti Suryalaya, seperti: rata-rata guru di Madrasah Aliyah Serba Bakti sudah dapat menyusun RPP dengan baik, menguasai teori belajar dan prinsip-prinsip pembelajaran, memahami potensi peserta didik, selalu berkomunikasi dengan peserta didik diluar jam pelajaran, dan selalu melakukan penilaian atau evaluasi pembelajaran.

Namun hal tersebut mendapat respon yang kurang baik dari peserta didik yakni seperti tidak adanya antusias yang tinggi untuk mengikuti pembelajaran. Sebagaimana informasi dari guru Madrasah Aliyah Serba Bakti Suryalaya bahwa masih ada beberapa peserta didik yang kurang memperhatikan dan bahkan mengerjakan aktivitas lain saat proses pembelajaran berlangsung, beberapa peserta didik yang bolos di jam-jam tertentu, dan beberapa peserta didik masih sering terlambat masuk kelas. Hal tersebut menandakan bahwa motivasi belajar peserta didik di Madrasah Aliyah Serba Bakti relatif rendah.

Adapun rumusan masalah dalam penelitian ini adalah (1) Bagaimana kompetensi pedagogik guru di Madrasah Aliyah Serba Bakti Pondok Pesantren Suryalaya?, (2) Bagaimana motivasi belajar peserta didik di Madrasah Aliyah Serba Bakti Pondok Pesantren Suryalaya?, (3) Bagaimana pengaruh kompetensi pedagogik guru terhadap motivasi belajar peserta didik di Madrasah Aliyah Serba Bakti Pondok Pesantren Suryalaya?

Berdasarkan rumusan masalah tersebut, maka tujuan penelitian yang dicapai adalah untuk mengetahui (1) Kompetensi pedagogik guru di Madrasah Aliyah Serba Bakti Pondok Pesantren Suryalaya, (2) Motivasi belajar peserta didik di Madrasah Aliyah Serba Bakti Pondok Pesantren Suryalaya, (3) Pengaruh kompetensi pedagogik guru tehadap motivasi belajar peserta didik di Madrasah Aliyah Serba Bakti Pondok Pesantren Suryalaya. 


\section{B. METODE}

Metode yang digunakan dalam penelitian ini adalah metode deskriptif dengan pendekatan kuantitatif. Metode deskriptif adalah metode penelitian yang berupaya untuk mengungkapkan keadaan atau kondisi yang terjadi saat sekarang dengan mempertimbangkan keadaan masa lampau, sehingga dapat diperoleh deskripsi atau gambaran secara sistematis, faktual, dan akurat mengenai fakta-fakta serta hubungan antar fenomena yang diteliti. (Wawan, t.t : 5).

Penelitian ini dilaksanakan sejak 1 Mei 2020 sampai dengan 30 Mei 2020 yang berlokasi di Madrasah Aliyah Serba Bakti Pondok Pesantren Suryalaya Kecamatan Pagerageung Kabupaten Tasikmalaya.

Instrumen penelitian yang digunakan pada penelitian ini yaitu observasi, dokumentasi, dan kuesioner. Adapun yang menjadi populasi dalam penelitian ini adalah seluruh peserta didik Madrasah Aliyah Serba Bakti Suryalaya yaitu berjumlah 357 peserta didik. Teknik pengambilan sampel yang digunakan dalam penelitian ini adalah teknik random sampling, dimana pengambilan anggota sampel dari populasi dilakukan secara acak tanpa memperhatikan strata yang ada dalam populasi tersebut. Adapun untuk menentukan banyaknya sampel yang akan diambil dari jumlah populasi yaitu diambil sebanyak $10 \%$ dan dilakukan perhitungan sebagai berikut:

$\frac{10}{100} \times 357=35,7 \approx 36$

Dan jumlah sampel yang akan diambil dalam penelitian ini yaitu sebanyak 36 peserta didik.

Teknik pengumpulan data yang digunakan yaitu berupa angket. Angket digunakan untuk mengumpulkan data dan memperoleh informasi mengenai kompetensi pedagogik guru dan motivasi belajar peserta didik. Dalam penelitian ini menggunakan angket tertutup, dimana responden diberikan alternatif jawaban, sehingga mereka tinggal memilih alternatif jawaban yang telah disediakan tersebut.

Teknik analisis data yang digunakan terdiri dari dua tahapan yaitu: Analisis deskriptif, digunakan untuk mendeskripsikan masing-masing variabel X dan Y. Analisis korelasi, digunakan untuk mengetahui besarnya pengaruh masing-masing komponen variabel bebas, yaitu diketahui dengan menggunakan koefisien korelasi rank spearman (rs).

\section{HASIL DAN PEMBAHASAN}

\section{Hasil}

Berdasarkan rumusan masalah penelitian dengan judul Pengaruh Kompetensi Pedagogik Guru terhadap Motivasi Belajar Peserta Didik didapat hasil sebagai berikut: Analisis kompetensi pedagogik guru (Variabel $\mathrm{X}$ ) menunjukan hasil kategori baik dengan nilai mean sebesar 56,7. Hal ini menunjukan bahwa kompetensi pedagogik guru di Madrasah Aliyah Serba Bakti Pondok Pesantren Suryalaya tergolong baik, yakni sebagian besar guru telah memenuhi indikator variabel $(\mathrm{X})$. 
Sebagaimana menurut teori yang dikemukakan oleh Mulyasa (2012: 75) bahwa kompetensi pedagogik guru sangat ditentukan oleh indikator kemampuan mengelola pembelajaran, pemahaman terhadap peserta didik, perencanaan pembelajaran, pelaksanaan pembelajaran yang mendidik dan dialogis, pemanfaatan teknologi pembelajaran, evaluasi hasil belajar, dan pengembangan peserta didik.

Pada realitas tersebut dapat dilihat dari rata-rata guru di Madrasah Aliyah Serba Bakti Pondok Pesantren Suryalaya sudah mampu mengelola pembelajaran dengan baik seperti pengaturan tempat duduk peserta didik supaya tercipta suasana belajar yang nyaman, dan senantiasa membagi kelompok secara heterogen ketika menggunakan metode diskusi. Selain itu guru di Madrasah Aliyah Serba Bakti juga dapat memahami peserta didik seperti pemahaman terhadap karakteristik masingmasing peserta didik, dan pemberian kesempatan belajar yang sama kepada setiap peserta didik. Perencanaan pembelajaran guru di Madrasah Aliyah Serba Bakti pun sudah baik, seperti sudah dapat menyusun RPP untuk setiap pertemuan dengan baik, dan mampu mempersiapkan pembelajaran dengan matang. Dalam pelaksanaan pembelajaran, guru di Madrasah Aliyah Serba Bakti sudah menggunakan metode yang berpariasi yang dapat menarik perhatian peserta didik, serta memberikan teladan yang baik terhadap peserta didik, guru pun selalu memberikan kesempatan bertanya kepada peserta didik mengenai materi ajar yang disampaikan. Dalam pemanfaatan teknologi pembelajaran, guru di Madrasah Aliyah Serba Bakti sudah mulai menggunakan teknologi audio-visual sebagai salah satu cara untuk meningkatkan motivasi belajar peserta didik, serta penggunaan internet sebagai pemanfaatan teknologi global supaya peserta didik bisa mendapatkan materi ajar yang lebih luas. Selanjutnya dalam pengevaluasian hasil belajar guru sudah menggunakan teknik evaluasi yang berpariatif sesuai dengan peraturan yang berlaku, serta melakukan penilaian secara objektif bagi setiap peserta didiknya. Guru di Madrasah Aliyah Serba Bakti pun peduli terhadap pengembangan peserta didik, hal ini dapat dilihat dari pengarahan bakat yang dimiliki peserta didik serta pemberian kesempatan belajar yang sesuai dengan cara belajar masing-masing peserta didik.

Analisis motivasi belajar peserta didik (Variabel Y) menunjukan hasil kategori cukup dengan nilai mean sebesar 54,8. Hal ini menunjukan bahwa motivasi belajar peserta didik di Madrasah Aliyah Serba Bakti Pondok Pesantren Suryalaya tergolong cukup, karena masih terdapat beberapa indikator yang belum terpenuhi.

\section{Pembahasan}

Sebagaimana menurut teori yang dikemukakan oleh Asrori (2019: 184) bahwa motivasi belajar peserta didik sangat ditentukan oleh indikator memiliki gairah yang tinggi, penuh semangat, memiliki rasa penasaran atau rasa ingin tahu yang tinggi, mampu "jalan sendiri" ketia guru meminta siswa mengerjakan sesuatu, memiliki rasa percaya diri, memiliki daya konsentrasi yang lebih tinggi, kesulitan dianggap sebagai tantangan yang harus diatasi, memiliki kesabaran dan daya juang yang tinggi.

Pada kenyataannya masih terdapat beberapa indikator yang belum terpenuhi yaitu peserta didik belum mampu "jalan sendiri" ketika guru meminta peserta didik 
mengerjakan sesuatu, serta peserta didik belum memiliki rasa percaya diri yang tinggi. Hal ini dapat dilihat dari beberapa peserta didik yang belum terdorong untuk memahami materi ajar sendiri ketika guru tidak masuk kelas, dan tidak mengerjakan tugas ketika guru tidak dapat masuk kelas, serta masih terdapat beberapa peserta didik yang mencontek ketika ulangan.

Sedangkan untuk indikator yang lainnya tergolong sudah terpenuhi, diantaranya peserta didik sudah memiliki gairah yang tinggi yang ditandai dengan antusiasnya peserta didik dalam mengikuti pembelajaran. Selain itu, semangat belajar peserta didik pun tergolong tinggi seperti hal nya ketika sudah memasuki jam pelajaran, peserta didik senantiasa mengingatkan guru untuk masuk kelas, serta peserta didik senantiasa masuk kelas tepat waktu. Rasa ingin tahu peserta didik juga tergolong tinggi, hal ini dapat dilihat dari antusias peserta didik untuk bertanya mengenai materi ajar yang belum mereka pahami. Selanjutnya peserta didik di Madrasah Aliyah Serba Bakti Suryalaya senantiasa menganggap kesulitan sebagai tantangan yang harus diatasi, seperti hal nya peserta didik tidak menghindari pelajaran yang tidak mereka sukai, serta senantiasa menanggapi pertanyaan yang diajukan guru ataupun peserta didik lainnya. Dalam belajar, peserta didik di Madrasah Aliyah Serba Bakti Suryalaya cenderung memiliki daya konsentrasi yang lebih tinggi, dalam hal ini dapat dilihat dari cepatnya peserta didik dalam memahami materi ajar, serta senantiasa menyelesaikan tugas yang di berikan guru dengan tepat. Di Madrasah Aliyah Serba Bakti Suryalaya, peserta didik senantiasa memiliki kesabaran dan daya juang yang tinggi, seperti hal nya mereka senantiasa mengikuti jam pelajaran dari awal sampai akhir, serta mengikuti pembelajaran tersebut dengan sungguh-sungguh.

Berdasarkan perhitungan korelasi antara variabel (X) dengan variabel (Y) dengan menggunakan rank spearman (rs), diperoleh harga rs sebesar 0,522. Angka korelasi rank spearman tersebut berada pada interval 0,41 - 0,60 dengan klasifikasi cukup (moderate), artinya terdapat pengaruh yang cukup antara kompetensi pedagogik guru terhadap motivasi belajar peserta didik di Madrasah Aliyah Serba Bakti Pondok Pesantren Suryalaya.

Derajat determinasi hubungan antara variabel $\mathrm{X}$ dan variabel $\mathrm{Y}$ adalah sebesar 27,25\%, hal ini menunjukan bahwa motivasi belajar peserta didik di Madrasah Aliyah Serba Bakti Pondok Pesantren Suryalaya ditentukan oleh kompetensi pedagogik guru sebesar $27,25 \%$, sedangkan sisanya $100 \%-27,25 \%=$ $72,75 \%$ dipengaruhi oleh faktor lain seperti dorongan dari orang tua, lingkungan sekolah, dorongan dari diri sendiri, dan lain sebagainya.

Melalui uji hipotesis diketahui bahwa $t_{\text {hitung }} 3,57 \geq t_{\text {tabel }}$ 1,691. Dengan demikian, dapat disimpulkan bahwa hipotesis alternatif $\left(\mathrm{H}_{\mathrm{a}}\right)$ yang menyatakan terdapat pengaruh positif yang signifikan antara kedua variabel tersebut diterima. 


\section{SIMPULAN}

Dengan berdasarkan kepada pembahasan, pengelolaan dan analisis data yang dilakukan maka dapat diambil simpulan sebagai berikut: kompetensi pedagogik guru berada pada klasifikasi baik, motivasi belajar peserta didik berada pada klasifikasi cukup, pengaruh kompetensi pedagogik guru terhadap motivasi belajar peserta didik di Madrasah Aliyah Serba Bakti Pondok Pesantren Suryalaya berada pada klasifikasi cukup.

Saran yang dapat diberikan adalah sebagai berikut: (1) Secara empirik, kompetensi pedagogik guru mempunyai pengaruh terhadap motivasi belajar peserta didik, maka diharapkan guru yang bersangkutan hendaknya terus meningkatkan kompetensi pedagogik yang dimiliki, walaupun kompetensi pedagogik guru di Madrasah Aliyah Serba Bakti Pondok Pesantren Suryalaya sudah tergolong baik, (2) Dalam hasil penelitian, motivasi belajar peserta didik berada di tingkat cukup. Mengingat hal tersebut, diharapkan peserta didik di Madrasah Aliyah Serba Bakti Pondok Pesantren Suryalaya mampu membangkitkan serta meningkatkan motivasi dalam belajar, karena motivasi belajar akan berpengaruh terhadap hasil dan prestasi belajar. Apabila motivasi belajar tinggi maka hasil yang didapat pun akan maksimal, (3) Bagi segenap pendidik di Madrasah Aliyah Serba Bakti Pondok Pesantren Suryalaya, karena kadar pengaruh kompetensi pedagogik guru terhadap motivasi belajar dihargai sebesar 27,25\%, maka motivasi belajar peserta didik juga dipengaruhi oleh faktor lainnya. Dengan demikian, diharapkan para pendidik mampu membangkitkan motivasi belajar peserta didik dari faktor lainnya, khususnya bagaimana cara membangkitkan motivasi belajar dari dalam diri peserta didik itu sendiri.

\section{DAFTAR PUSTAKA}

Alfabeta Tim. (2015). Pedoman Penulisan Karya Tulis Ilmiah. Fakultas Tarbiyah.

Asrori, Mohammad. (2019). Psikologi Pembelajaran. Bandung: Wacana Prima.

Ernata, Yusvidha. (2017). "Analisis Motivasi Belajar Peserta Didik Melalui Pemberian Reward dan Punishment". Jurnal Pemikiran dan Pengembangan SD, Vol. 5, No. 2, 782.

Jamal, Muh Nurfauzi. (2017). Pengaruh Kompetensi Pedagogik Guru Terhadap Motivasi Belajar Peserta Didik Madrasah Aliyah Abnaul Amir Kabupaten Gowa. Skripsi Sarjana (dipublikasikan). Makassar: Fakultas Tarbiyah dan Keguruan Universitas Islam Negeri Alauiddin Makassar. Diambil 28 Oktober 2019 dari https://scholar.google.com.

Mulyasa E. (2012). Standar Kompetensi dan Sertifikasi Guru. Bandung: Remaja Rosda Karya.

Tim Penerjemah Al-Qur'an Depag RI, (2009). Syaamil Qur'an. Bandung: Sygma Examedia Arkanleema.

Wawan. (tanpa tahun terbit). Desain Penelitian Kuantitatif. Tasikmalaya: Latifah Press. (tanpa tahun terbit). Pengantar Statistika Pendidikan. Tasikmalaya: Latifah Press. 